\title{
EFFECT OF BORE FLUID COMPOSITION ON STRUCTURAL AND PERFORMANCE OF POLYPHENYLSULFONE HOLLOW FIBER MEMBRANE CONTACTOR FOR DEACDIFICATION OF CRUDE PALM OIL
}

\author{
(Kesan Komposisi Cecair Lubang pada Struktur dan Prestasi Membran Gentian Geronggang \\ Polifenilsulfona Membran Kontaktor untuk Penyahasidan Minyak Sawit Mentah)
}

\author{
Noor Hidayu Othman ${ }^{1,2}$, Ahmadilfitri Md Noor ${ }^{1}$, Mohd Suria Affandi Yusoff ${ }^{1}$, Pei Sean Goh ${ }^{2}$, \\ Ahmad Fauzi Ismail ${ }^{2}$, Woei Jye $\mathrm{Lau}^{2}$, Be Cheer $\mathrm{Ng}^{2}$, Norafiqah Ismail ${ }^{2}$ \\ ${ }^{1}$ Sime Darby R\&D Centre Downstream, \\ 42960 Pulau Carey, Selangor, Malaysia \\ ${ }^{2}$ Advanced Membrane Technology Research Centre (AMTEC), \\ Universiti Teknologi Malaysia, 81310 UTM Skudai, Johor Darul Takzim, Malaysia \\ *Corresponding author: noor.hidayu.othman@simedarby.com
}

Received: 26 August 2016; Accepted: 8 January 2017

\begin{abstract}
The present work is aimed to study the influence of membrane internal structure on the extracting performance of hollow fiber membrane contactor system in removing free fatty acid (FFA) from crude palm oil (CPO). Polyphenylsulfone (PPSU) hollow fiber membrane were prepared via wet spinning method. Different bore fluid composition were employed mainly consisted of distilled water in combination with $0,20,30$ and $40 \mathrm{wt} . \% \mathrm{~N}$-methyl-2pyrrolidone (NMP). The resulting membranes structure were characterized for membrane morphology, membrane wettability and membrane pore size. The used of pure distilled water as membrane BF had created a large macrovoid structure with uniform and tiny finger-liked morphology at the outer membrane layer. Meanwhile, the present of NMP in BF composition had obviously changed the internal layer of 14PPSU membrane to more interconnected double-layers of finger-liked morphology. However, there are not much different in membrane wettability and pore size of 14PPSU membrane were recorded. All PPSU hollow fiber membranes were further evaluated for deacidification performance through membrane contactor with sodium hydroxide $(\mathrm{NaOH})$ as liquid extractant. 14PPSU-100:0 membrane contactor that prepared from $100 \%$ distilled water as BF composition demonstrated the highest FFA removal of $16.54 \%$ without soap formation in oil permeate stream.
\end{abstract}

Keywords: polyphenylsulfone, membrane contactor, sodium hydroxide, free fatty acids, crude palm oil

\begin{abstract}
Abstrak
Hasil kerja ini bertujuan untuk mengkaji pengaruh struktur dalaman membran kepada prestasi pengekstrakan gentian geronggang membran kontaktor sistem dalam mengeluarkan asid lemak bebas (FFA) daripada minyak sawit mentah (MSM). Membran polifenilsulfona gentian geronggang telah disediakan melalui teknik fasa balikan basah. Komposisi cecair lubang yang berbeza telah digunakan dimana sebahagian besarnya terdiri daripada air suling dengan kombinasi 0, 20, 30 dan 40 wt.\% berat N-metil2pirolidon (NMP). Struktur membran yang dihasilkan telah diperincikan kepada morfologi membran, kebolehbasahan membran dan saiz liang membran. Penggunaan air suling tulen sebagai cecair lubang telah mewujudkan struktur ruang makro dengan morfologi seperti jejari kecil dan sekata pada lapisan luar membran. Sementara itu, kehadiran NMP dalam komposisi cecair lubang dengan jelas telah mengubah lapisan dalaman membran 14PPSU untuk saling berhubung diantara dua lapisan morfologi jejari. Walau bagaimanapun, tiada perbezaan ketara pada kebasahan dan saiz liang membran 14PPSU telah direkodkan. Semua membran PPSU gentian geronggang telah dinilai pada prestasi penyahasidan melalui membran kontaktor bersama natrium hidroksida $(\mathrm{NaOH})$ sebagai cecair pengekstrak. Membran 14PPSU-100:0 kontaktor yang dihasilkan daripada 100\% air suling
\end{abstract}




\section{Noor Hidayu et al: $\quad$ EFFECT OF BORE FLUID COMPOSITION ON STRUCTURAL AND PERFORMANCE OF POLYPHENYLSULFONE HOLLOW FIBER MEMBRANE CONTACTOR FOR DEACDIFICATION OF CRUDE PALM OIL}

sebagai komposisi cecair lubang telah menunjukkan penyingkiran FFA tertinggi sebanyak $16.54 \%$ tanpa pembentukan sabun dalam aliran minyak.

Kata kunci: polifenilsulfona, kontaktor membran, natrium hidroksida, asid lemak bebas, minyak sawit mentah

\section{Introduction}

In palm oil industry, refining process involves the removal of undesirable constituents such as FFA, phospholipid, colour pigment and trace elements from crude palm oil (CPO) in order to achieve the required quality and stability of refined oil. Chemical and physical refining processes are the most common methods that has been applied in palm oil industry. Deacidification or the removal of free fatty acid (FFA) are conducted at different processing stage between these two refining approached. In chemical refining, the FFA is removed during neutralization stage in the formed of soapstock after reacted with sodium hydroxide $(\mathrm{NaOH})$. In physical refining, the FFA is removed during deodorization stage by steam distillation at high temperature of $260-265{ }^{\circ} \mathrm{C}$ [1]. However, several drawbacks are identified from conventional refining processes such as high energy usage, losses of neutral oil and large amount of water and chemical usage had heavily produced a contaminated effluents [2].

Membrane technology is one of new deacidification approaches that can be further explore in order to overcome the drawbacks of conventional deacidification practices. It is due to advantages of low energy consumption, mild temperature operation and retention of nutrients and other desirable components [3]. Nevertheless, FFA in principle is almost impossible to be removed by membranes itself due to smaller molecular size of FFA $(<300 \mathrm{Da})$ than the triglycerides $(\sim 900 \mathrm{Da})$. Theoretically, the ideal process would be to use a precise membrane pores size that could effectively separate the FFAs from the triglycerides [4].

In order to overcome the abovementioned limitation, membrane contactor technology is chosen for deacidification of CPO due to the advantages of liquid-liquid mass transfer without dispersion of one phase within another. In membrane contactors system, the membrane separation is fully integrated with another separation technology called extraction process in order to exploit the benefits of both technologies in improving the removal of FFA from CPO. The fluids to be contacted are flowed on the opposite sides of the membrane and the fluid/fluid interface forms at the mouth of each membrane pore. Mass transfer occurs by diffusion across the interface. The driving force for separation is a concentration rather than a pressure gradient; indeed only a very small pressure drop across the membrane is required to ensure that the fluid/fluid interface remains immobilized at the mouth of the pore [5].

Polyphenylsulfone (PPSU) membrane was chosen as a main polymer for membrane contactor system. Although PPSU is relatively new in the polysulfone family, it has a vast potential in various membrane applications, such as fuel cell [6], pervaporation [7], gas separation [8] and water treatment process [9]. PPSU that comprises sulfone moieties, ether linkages and biphenyl group in its repeat group have the highest impact strength compared with the other family members [10]. It presents superior resistant to hydrolysis and plasticization of stress cracking. The robustness of PPSU membrane in terms of physical durability and high tolerance to chemical resistance has standout as a remarkable polymer candidate, which could be potentially developed for further use in CPO deacidification [7].

A dry-jet wet spinning method usually employed a tube-in-orifice spinneret that transfer the nascent fiber through an air gap before it enters the coagulation bath. The shell surface structure can be controlled by the air gap length and the environment of the surrounding including relative humidity, temperature, organic vapor etc. Whereas, the bore fluid (BF) composition controlled the bore side structure [11]. Dong et al. [12] investigated the effect of various membrane fabrication parameters on the structure and separation performance of hollow fiber (HF) membrane for gas separation. They found that increasing NMP to water in BF composition had suppressed the finger-liked macrovoids and the sponge-like structure becomes predominant. Feng et al. [13] investigated on the PVDF-HF membrane fabrication using various N-methyl-2-pyrrolidone (NMP) aqueous solutions as an inner coagulant. They found that the PVDF membrane morphology had gradually shifted from a double-skin to a singleskin structure with the increased in NMP concentration. 
The aimed of current research work is to study the influence of membrane internal structure at different $\mathrm{BF}$ composition (water/NMP) on the extracting performance of membrane contactor. It is generally known that changing the $\mathrm{BF}$ composition will change the membrane internal structure due to low solvent/non solvent exchange rate upon addition of solvent into bore fluid. The addition of NMP into BF composition could delay the demixing process, produce more porous membrane structure and better mass transport of solute (FFA) towards the liquid extractant for effective deacidification of $\mathrm{CPO}$. $\mathrm{NaOH}$ is used as liquid extractant in PPSU membrane contactor system due to high affinity towards FFA. The interfacial contact between $\mathrm{NaOH}$ and $\mathrm{CPO}$ that immobilized in the membrane pores could serve as a good platform in extracting the FFA without contaminating the CPO with soap formation. Hence, it could prevent the oil loss throughout the process as well as an attractive solution towards "solvent-free" technology.

\section{Materials}

\section{Materials and Methods}

PPSU membrane polymer was purchased from Sigma-Aldrich. N-methyl-2pyrrolidone (NMP) was bought from Merck and used as a solvent in membrane dope solution and bore fluid composition. CPO was obtained from Sime Darby Jomalina Sdn. Bhd. (Telok Panglima Garang, Selangor,Malaysia). Sodium Hydroxide (NaOH) was used as liquid extractant for membrane contactor system. All chemicals used in this work were received without further treatment.

\section{Preparation of dope solution}

Three membrane dope solution were prepared from a combination of $14 \%$ PPSU membrane and $86 \%$ NMP. Both polymer and solvent were mixed thoroughly under constant mechanical stirring at $60{ }^{\circ} \mathrm{C}$ for 1 day in order to produce a homogenous solution. Then the formulated dope solution was degassed before spinning to remove the micro-bubbles.

\section{Fabrication of PPSU hollow fiber membrane}

The HF membranes were fabricated according to the well-known wet spinning method. The dope was place in a stainless steel dope reservoir (volume: 1 liter) that was subsequently pump to the spinneret by a gear pump. The dope reservoir that contains polymer solution was kept under nitrogen pressure as a precaution against cavitation in the line to the pump. Then a pulse-free BF was fed into the inner tube of the spinneret by a syringe pump. Once the spinning dope and the BF met at the tip of the spinneret, they went into the external coagulation bath after going through zero air gap. The details spinning parameter of HF membrane is shown in Table 1 . The nascent fibers were then passed through the washing/treatment bath before collected properly by a wind-up drum.

\section{Membrane post-treatment}

The as-spun fibers were cut in pieces of approximately $40 \mathrm{~cm}$ in length and immersed in water bath at room temperature for 1 day to remove residual solvent from the membrane structure. Then the nascent HF membrane were post-treated with water/ ethanol (1:1) solution for 30 minutes, followed by pure ethanol solution for another 30 minutes to prevent fiber shrinkage. Finally, the fibers were hang vertically and air dried at room temperature for about 1 day before membrane characterization and preparation of membrane module.

\section{Membrane contactor module}

A total of 100 pieces of HF membrane were potted inside the PVC pipe for membrane contactor performance testing. An epoxy adhesive resin (Polyurethane E-30CL Loctite) was used as the potting resin. This resin was chosen due to its suitable cure times, low viscosity and proper adhesion with the PVC and steel tubing. Table 2 shows the detail specification of HF membrane contactor module.

\section{Membrane characterization}

PPSU membrane cross-sectional images was observed using table-top scanning electron microscope (SEM, Model: TM 3000, Hitachi). All specimens were freeze-dried and coated with an ultra-thin layer of gold before characterisation. Prior to analysis, a piece of hollow fiber was immersed in a liquid nitrogen and fractured carefully in order to create a perfect cross section. 


\section{Noor Hidayu et al: EFFECT OF BORE FLUID COMPOSITION ON STRUCTURAL AND PERFORMANCE OF POLYPHENYLSULFONE HOLLOW FIBER MEMBRANE CONTACTOR FOR DEACDIFICATION OF CRUDE PALM OIL}

Table 1. Spinning parameters for fabrication of PPSU-HF membrane

\begin{tabular}{lc}
\hline Spinning Parameter & Composition \\
\hline Spinning solution & 14PPSU/86NMP \\
Bore fluid composition & Distilled water/ NMP \\
(a) 14PPSU-80:20 & $80 / 20$ \\
(b) 14PPSU-70:30 & $70 / 30$ \\
(c) 14PPSU-60:40 & $60 / 40$ \\
Inner diameter of spinneret $(\mathrm{mm})$ & 0.55 \\
Outer diameter of spinneret $(\mathrm{mm})$ & 1.25 \\
Air gap (mm) & 0 \\
Dope extrusion rate $\left(\mathrm{cm}^{3} / \mathrm{min}\right)$ & 7.2 \\
Bore fluid flow rate $(\mathrm{ml} / \mathrm{min})$ & 2.2 \\
Take-up rate $(\mathrm{rpm} / \mathrm{min})$ & 24 \\
Spinning temperature $\left({ }^{\circ} \mathrm{C}\right)$ & 27 \\
External coagulant & Distilled water \\
Coagulation bath temperature $\left({ }^{\circ} \mathrm{C}\right)$ & 25 \\
\hline
\end{tabular}

Table 2. Specification of HF membrane contactor module

\begin{tabular}{lc}
\hline Membrane Specification & Value \\
\hline Module i.d. (mm) & 35 \\
Module length (mm) & 400 \\
Fiber o.d. (mm) & 0.55 \\
Fiber i.d. (mm) & 1.25 \\
Effective fiber lengh (mm) & 330 \\
No. of fibers & 100 \\
\hline
\end{tabular}

The membrane wettability property of HF membrane was evaluated by sessile drop method using contact angle goniometer (Model: OCA15Plus, Dataphysics, Germany) equipped with images processing software. A total of 10 contact angle measurement were recorded from each sample to get more accurate and average reading.

The field emission scanning electron microscopy (FESEM) (Hitachi model S-900) was used to capture the membrane images with magnifications ranging from 10,000 to 50,000. The electron beam was accelerated under a $3.0 \mathrm{kV}$ in the vacuum chamber. The images obtained from the FESEM were analyzed by the software 'AnalySIS' provided by Soft Imaging System. The pores area was measured by encircling the membrane pores.

\section{Lab-scale hollow fiber membrane contactor system}

Figure 1 shows a schematic diagram of membrane contactor system for CPO deacidification. The pressure was set at 0.1 bar for both $\mathrm{CPO}$ stream (1) and $\mathrm{NaOH}$ stream (2). Initially, $\mathrm{CPO}$ was subjected to pre-treatment process to remove gums (phospholipids) before deacidification process. The treated CPO was heated and maintained at 50 to $60^{\circ} \mathrm{C}$ when passing through membrane contactor module within the membrane housing (shell-side), whereas the $\mathrm{NaOH}$ was circulated inside the lumen (tube-side) of PPSU membrane (Figure 2). The interfacial contact between $\mathrm{CPO}$ and $\mathrm{NaOH}$ occurred at the mouth of membrane pores for FFA extraction towards the liquid extractant. $200 \mathrm{ml}$ permeate oil was collected every 30 min time interval for 3 hours for FFA and soap content analysis. 


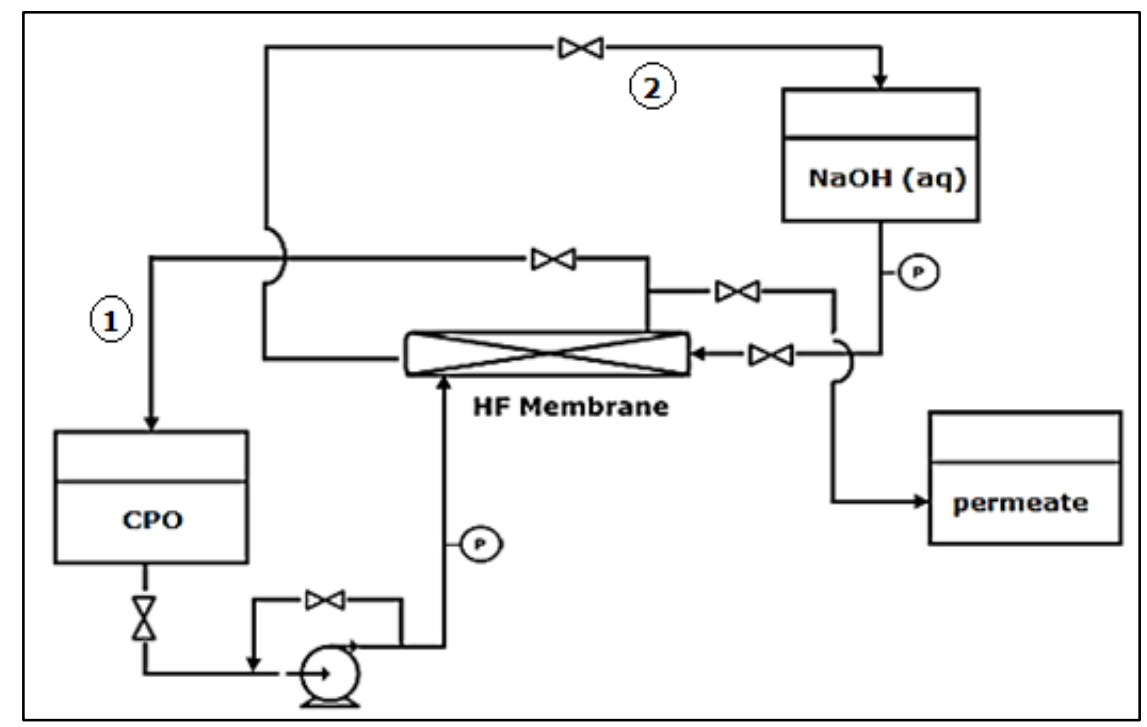

Figure 1. Schematic diagram of HF membrane contactor system

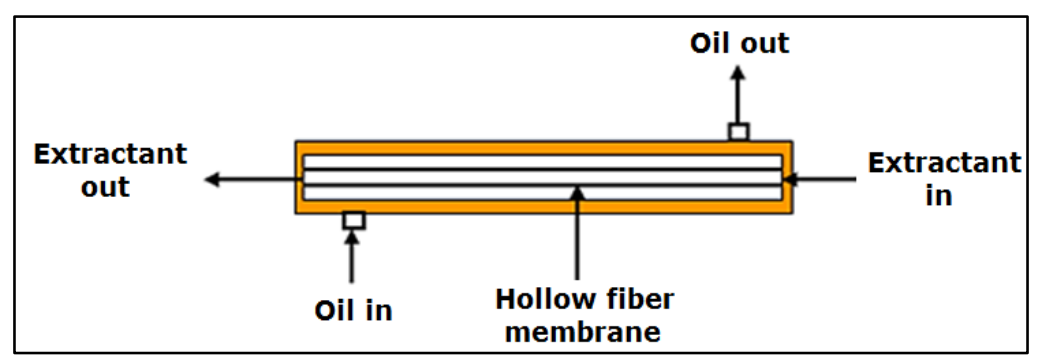

Figure 2. Flow direction of $\mathrm{CPO}$ stream and $\mathrm{NaOH}$ stream within a membrane housing

\section{Oil analysis}

Free fatty acid (FFA) and soap content in the oil samples was determined according to the American Oil Chemists' Society (AOCS) Official Method - Ca 5a-40 and Cc 17-95, respectively.

\section{Statistical analysis}

Statistical analysis software (Minitab 17) was used to perform statistical analysis for R-square and P-value. The analysis of variance (ANOVA) with Tukey pairwise comparison was performed to determine the significant difference at $\mathrm{P}<0.05$. Analysis was conducted in triplicates.

\section{Membrane morphology}

\section{Results and Discussion}

The influence of internal coagulant on HF membrane properties has been investigated by many researchers. It was found that the addition of solvent into the internal coagulant significantly reduced the precipitation rate. The formation of hollow fiber is based on the solvent/non-solvent exchange mechanism. The used of distilled water as membrane BF due to significant concentration gradient results in a rapid exchanged mechanism. The exchanged mechanism is significantly slower when the BF contains solvent $[14,15]$. 


\section{Noor Hidayu et al: $\quad$ EFFECT OF BORE FLUID COMPOSITION ON STRUCTURAL AND PERFORMANCE OF POLYPHENYLSULFONE HOLLOW FIBER MEMBRANE CONTACTOR FOR DEACDIFICATION OF CRUDE PALM OIL}

The most two important parameters that influences the membrane properties are type of solvent and polymer concentration in membrane dope solution. 14PPSU-100 HF membrane that fabricated using $100 \%$ distilled water as BF composition had produced a tiny finger-liked morphology near the outer membrane surface with a large macrovoid structure in the central core membrane layer as shown in Figure 3 (a). The present of 20\% NMP in combination with $80 \%$ distilled water as BF composition had changed the internal structure of 14PPSU-80:20 HF membrane to a prominent double-layer finger-liked morphology with bigger microvoid structure at the inner membrane layer compared to the outer part (Figure 3b). Apparently, the double-layer finger-liked morphology of 14PPSU-70:30 HF membrane became thicker especially at the inner membrane layer with the present of 30\% NMP in membrane BF while the bottom structures of skin layer remains unchanged (Figure 3c). Further increased of solvent (40\%NMP/ $60 \%$ distilled water) in membrane BF composition made 14PPSU-60:40 HF membrane became more porous compared to 14PPSU-70:30 HF membrane with more uniform and interconnected finger-liked morphology between the inner and outer membrane layers.

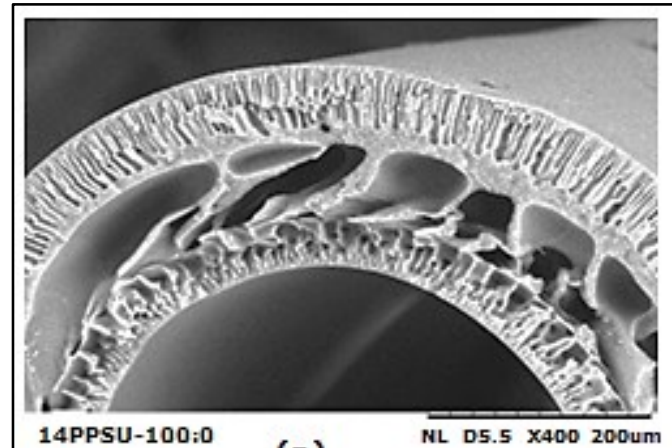

(a)

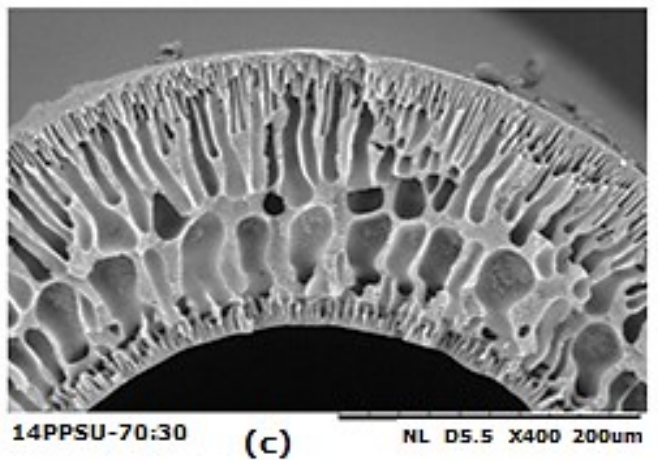

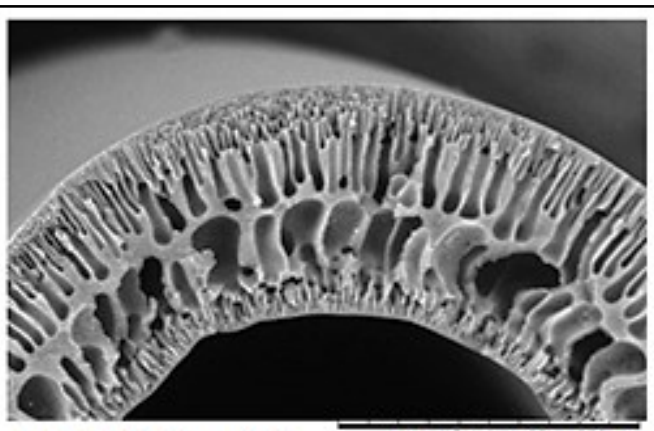

(b)

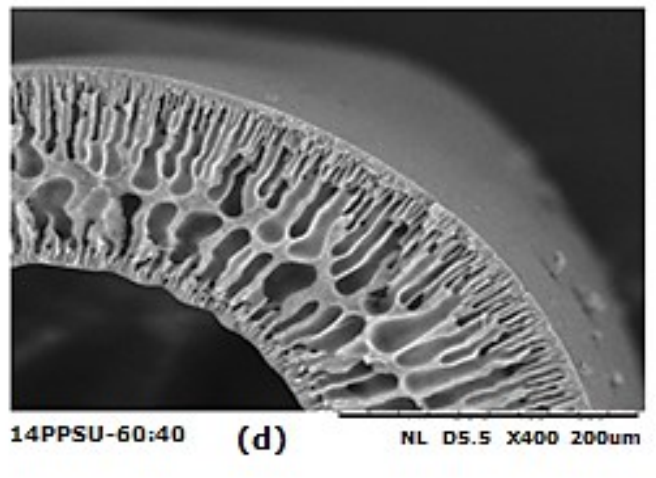

Figure 3. SEM cross-sectional images (400X magnification) of 14PPSU with different bore fluid ratio of water: NMP (a) 100:0 (b) 80:20 (c) 70:30 (d) 60:40

These is an agreement with Rahbari-sisakht et al. [15] which explained that as NMP concentration in the BF increased, the inner surface becomes more porous because the solvent out flux from the polymer solution phase to the coagulant phase is suppressed in the presence of solvent (NMP) in the coagulant. As the consequences, a large amount of NMP remains at the polymer solution/coagulant interface, preventing the formation of dense skin layer. However, the results obtained was contradict with finding from Feng et al. [13].They found that increased in NMP concentration had shifted a double-skin to a single-skin structure of PVDF hollow fiber membrane. It may due to different membrane polymer have different membrane morphology that acted differently although membrane fabrication is subjected to similar BF composition. 


\section{Membrane wettability}

Table 3 shows the membrane contact angle of 14PPSU membrane at different water/NMP as BF composition. It can be observed that more than $20 \%$ NMP present in $\mathrm{BF}$ composition had significantly $(\mathrm{P}<0.05)$ reduced the hydrophobicity of $14 \mathrm{PPSU}$ membrane from $85.23^{\circ}(0 \% \mathrm{NMP})$ to $81.46^{\circ}(30 \% \mathrm{NMP})$ and $81.11^{\circ}(40 \% \mathrm{NMP})$, respectively.

Table 3. Membrane contact angle of 14PPSU membrane at different bore fluid composition of water: NMP

\begin{tabular}{lc}
\hline Membrane & Contact Angle (0) \\
\hline 14PPSU-100:0 & $85.23 \pm 0.77^{\mathrm{A}}$ \\
14PPSU-80:20 & $83.54 \pm 1.57^{\mathrm{A}}$ \\
14PPSU-70:30 & $81.46 \pm 0.70^{\mathrm{B}}$ \\
14PPSU-60:40 & $81.11 \pm 1.52^{\mathrm{B}}$ \\
\hline
\end{tabular}

Each value in table represents the mean \pm standard deviation of sample analysis from triplicate analysis. Mean within column with different superscripts letter A, B are significantly different $(P<0.05)$.

\section{Membrane pore size}

Table 4 shows the range and mean pore size of 14PPSU membrane characterized by images analysis from FESEM micrograph. Statistically, the present of $20 \% \mathrm{NMP}$ in BF composition had significantly $(\mathrm{P}<0.05)$ increased the mean pore size of $14 \mathrm{PPSU}$ membrane from $24.81 \mathrm{~nm}$ to $30.49 \mathrm{~nm}$, respectively. However, further increased in NMP composition resulted in a fluctuation of membrane pore size but it has no significant different $(\mathrm{P}<0.05)$ from 14PPSU produced from $100 \%$ distilled water as BF composition. A poor correlation $(\mathrm{R} 2=0.2898$ ) was recorded between the different in BF composition and membrane pore size of 14PPSU membrane.

Table 4. Membrane pore size of 14PPSU membranes at different BF composition (H2O: NMP)

\begin{tabular}{lcc}
\hline Membrane & Range Pore Size (nm) & Mean Pore Size (nm) \\
\hline 14PPSU-100:0 & 22.3 to 31.3 & $24.81 \pm 3.07^{\mathrm{B}}$ \\
14PPSU-80:20 & 22.3 to 35.7 & $30.49 \pm 6.51^{\mathrm{A}}$ \\
14PPSU-70:30 & 17.8 to 26.8 & $23.59 \pm 2.78^{\mathrm{B}}$ \\
14PPSU-60:40 & 22.3 to 32.97 & $26.01 \pm 3.92^{\mathrm{AB}}$ \\
\hline
\end{tabular}

Each value in table represents the mean \pm standard deviation of sample analysis from triplicate analysis. Mean within column with different superscripts letter A, B are significantly different $(P<0.05)$.

\section{PPSU membrane contactor performance: FFA removal and soap formation}

The selection of proper BF composition had a big impact on the membrane contactor performance in removing the FFA. As shown by Figure 4, 14PPSU-100 had the most promising results with high initial FFA removal of $12 \%$ after $30 \mathrm{~min}$, followed by $12.86 \%$ FFA removal after $120 \mathrm{~min}$ and up to $16.54 \%$ FFA removal after $180 \mathrm{~min}$ of permeate collected throughout the process although there are some fluctuation in between the time intervals. Unfortunately, changing the internal membrane structure by adding the NMP into BF composition had tremendously reduced the deacidification performance of membrane contactor system. It can be seen clearly a significant $(\mathrm{P}<0.05)$ reduction in FFA removal when NMP was added into BF composition. 14PPSU-80:20 did not favour FFA removal at all. Meanwhile both 14PPSU-70:30 and 14PPSU-60:40 had only $2.5 \%$ and 2.3\% FFA removal, respectively after 3 hours permeate collection. Although the present of NMP in BF composition had 


\section{Noor Hidayu et al: EFFECT OF BORE FLUID COMPOSITION ON STRUCTURAL AND PERFORMANCE OF POLYPHENYLSULFONE HOLLOW FIBER MEMBRANE CONTACTOR FOR DEACDIFICATION OF CRUDE PALM OIL}

slightly changed the membrane hydrophobicity and membrane pore size, a predominant changed in internal membrane structure from a large macrovoid with tiny finger-like morphology on the upper membrane layer (BF: $100 \%$ distilled water) to interconnected double-layers finger-like morphology had reduced the immobilisation of $\mathrm{CPO}$ towards $\mathrm{NaOH}$ at the mouth of membrane pores. It may due to the reduction in $\mathrm{CPO}$ volume localisation inside the internal membrane structure. Besides, the present of central core skin layer that separated double-layer finger-liked morphology had created a barrier and obstructing the mass transfer of FFA towards $\mathrm{NaOH}$.

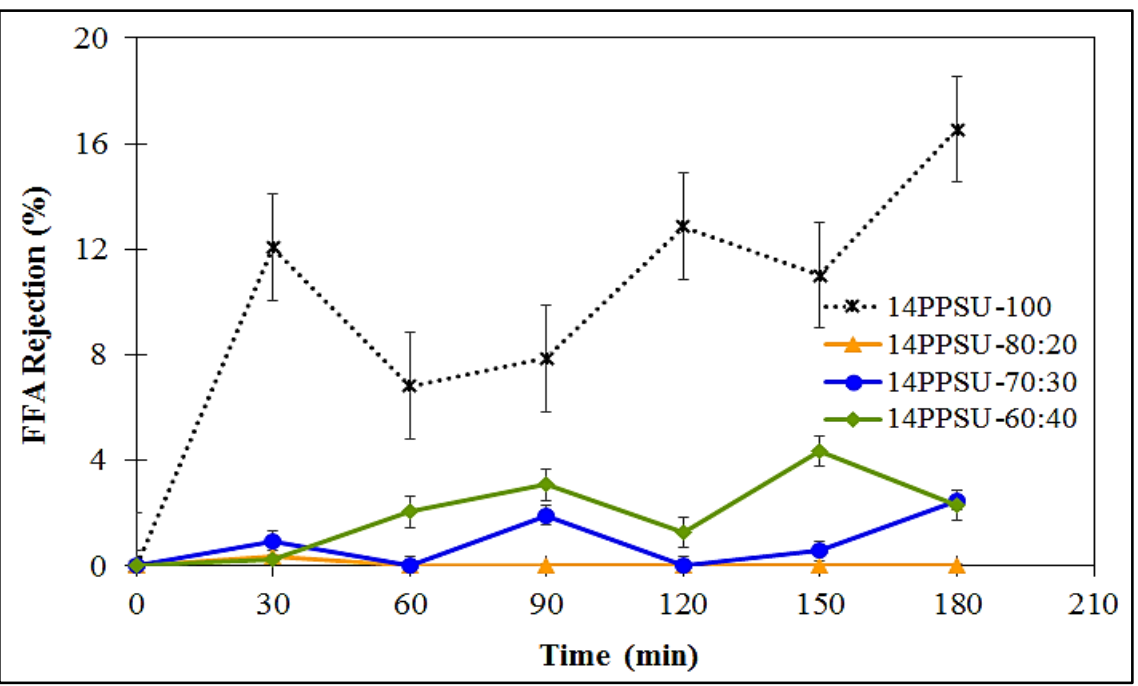

Figure 4. FFA rejection of 14PPSU membranes at different bore fluid composition

For the practical application, it is of great importance to ensure that the membrane contactor system could remove FFA from feed CPO without contaminating the permeate oil with soap formation to avoid neutral oil loss. PPSU is chosen in this study due to its hydrophobicity that allows the oil to wet the membrane layer and prevent the $\mathrm{NaOH}$ from penetrating into $\mathrm{CPO}$ stream. Besides, the operating pressure for both $\mathrm{CPO}$ and $\mathrm{NaOH}$ stream was properly established to facilitate FFA extraction and limit the penetration between the two separated streams at the membrane interface only. Although the deacidification performance was not favourable with the present of NMP in BF composition, but the robustness of all PPSU membrane with regards to chemical resistance cannot be denial. Table 5 showed that no soap formation was detected in all permeate samples throughout 3 hours operation.

Table 5. Soap content analysis of permeate oil sample collected from membrane contactor performance

\begin{tabular}{lcccc}
\hline \multirow{2}{*}{ Membrane Modules } & \multicolumn{4}{c}{ Soap Content (ppm) } \\
\cline { 2 - 5 } & $\begin{array}{c}\text { 14PPSU-100 } \\
\text { (water) }\end{array}$ & $\begin{array}{c}\text { 14PPSU-80:20 } \\
\text { (water: NMP) }\end{array}$ & $\begin{array}{c}\text { 14PPSU-70:30 } \\
\text { (water: NMP) }\end{array}$ & $\begin{array}{c}\text { 14PPSU-60:40 } \\
\text { (water: NMP) }\end{array}$ \\
\hline Feed oil & n/a & n/a & n/a & n/a \\
Permeate: After & & & & nil \\
30 min & nil & nil & nil & nil \\
60 min & nil & nil & nil & nil \\
90 min & nil & nil & nil & nil \\
120 min & nil & nil & nil & nil \\
150 min & nil & nil & nil & nil \\
180 min & nil & nil & nil & \\
\hline
\end{tabular}




\section{Conclusion}

It can be concluded that proper selection of $\mathrm{BF}$ composition employed during membrane fabrication had provides a big different for the performance of membrane contactor system in removing the FFA in CPO. Different BF composition employed during membrane fabrication had prominently changed the internal membrane structure of 14PPSU membrane with slightly changed in membrane wettability and membrane pore size. The combination of distilled water/NMP in BF composition had changed the internal layer of 14PPSU membrane from tiny finger-liked morphology with larger macrovoid structure to more interconnected double-layers finger-liked morphology. For CPO deacidification process, $100 \%$ distilled water was the most suitable BF composition in producing 14PPSU-HF membrane due to its promising results with the highest FFA removal of $16.54 \%$ recorded without soap formation. For future work in this research area, it is recommended to investigate on the effect of dope extrusion rate (DER) during spinning process in order to understand the rheological influence of phase inversion in membrane production and separation performance of HF membrane contactor system.

\section{Acknowledgement}

The author (N.H. Othman) is thankful to Sime Darby Research Sdn. Bhd. for supplying crude palm oil and other financial support, and to the members of Advanced Membrane Technology Centre (AMTEC), UTM Skudai, Johor for technical support. P.S. Goh and A.F. Ismail would like to acknowledge HiCOE Grants 4J182 and 4J204 under Ministry of Higher Education for the financial support.

\section{References}

1. Bhosle, B. and Subramanian, R. (2005). New approaches in deacidification of edible oils - A review. Journal of Food Engineering, (69): 481 - 494.

2. Gibon, V., Greyt, W. and Kellens, M. (2007). Palm oil refining. European Journal of Lipid Science and Technology, (109): $315-335$.

3. Koseoglu, S. S and Engelgau, D. E. (1990). Membrane application and research in the edible oil industry: An assessment. Journal of the American Oil Chemists' Society, (67): 239 - 249.

4. Cheryan, M. (2005). Membrane technology in the vegetable oil industry. Membrane Technology, (2): 5 - 7.

5. Hwang, S. and Gabelman, A. (1999). Hollow fiber membrane contactors. Journal of Membrane Science, (159): $61-106$.

6. Decker, B., Hartmann, C.-T., Carver, P. I., Keinath, S. E. and Santurri, P. R. (2010). Multilayer sulfonated polyhedral oligosilsesquioxane (S-POSS) sulfonated polyphenylsulfone (S-PPSU) composite proton exchange membranes. Chemistry of Materials, 22(3): 942 - 948.

7. Jullok, N., Darvishmanesh, S., Luis, P. and Van der Bruggen, B. (2011). The potential of pervaporation for separation of acetic acid and water mixtures using polyphenylsulphone Membranes. Chemical Engineering Journal, 175: $306-315$.

8. Weng, T.-H. , Tseng, H.-H. and Wey, M.-Y. (2008). Preparation and characterisation of PPSU/PBNPI blend membrane for hydrogen separation. International Journal of Hydrogen Energy, 33(15): 4178 - 4182.

9. Sani, N., Lau, W. and Ismail, A. F. (2015). Morphologies and separation characteristics of polyphenylsulfonebased solvent resistant nanofiltration membranes: Effect of polymer concentration in casting solution and membrane pretreatment condition. Korean Journal of Chemical Engineering, 32(4): 743 - 752.

10. Scheirs, J. (2000). Compositional and failure analysis of polymers: A practical approach. John Wiley \& Sons. England.

11. Liu, Y., Koops, G. H. and Strathmann, H. (2003). Characterization of morphology controlled polyethersulfone hollow fiber membranes by the addition of polyethylene glycol to the dope and bore liquid solution. Journal of Membrane Science, 223: 187 - 199.

12. Dong, G., Li, H. and Chen, V. (2010). Factors affect defect-free matrimid hollow fiber gas separation performance in natural gas purification. Journal of Membrane Science, 353: 17 - 27.

13. Feng, R. C., Wang, H. and Zhang, L. S. (2011). Diverse morphologies of PVDF hollow fiber membranes and their performance analysis as gas/liquid contactors. Journal of Applied Polymer Science, 119: 1259 - 1267.

14. Rahbari-sisakht, M., Ismail, A. F. and Matsuura, T. (2012). Effect of bore fluid composition on structure and performance of asymmetric polysulfone hollow fiber membrane contactor for $\mathrm{CO}_{2}$ Absorption. Separation and Purification Technology, 88: 99 - 106. 
Noor Hidayu et al: $\quad$ EFFECT OF BORE FLUID COMPOSITION ON STRUCTURAL AND PERFORMANCE OF POLYPHENYLSULFONE HOLLOW FIBER MEMBRANE CONTACTOR FOR DEACDIFICATION OF CRUDE PALM OIL

15. Yan, J. and Lau, W. (1998). Effect of internal coagulation morphology of polysulfone hollow fiber membranes. Separation and Science Technology, 33(1): 33 - 55. 